\title{
KOMMENTTI
}

\section{Tutkijasta fysioterapeutiksi}

\begin{abstract}
Alanvaihto toi mukanaan uuden ammatin lisäksi ihmissuhteita, työyhteisön. Ammatillinen identiteetti muovautuu työtä tehdessä.
\end{abstract}

OLEN TYÖSKENNELLYT UUDESSA ammatissani fysioterapeuttina kuluvan vuoden alusta lähtien. Takana on usean vuoden mittainen alanvaihtoprosessi, joka sai alkunsa, kun havahduin haluuni tehdä työkseni jotakin muuta kuin yliopistotutkijan työtä. Kiinnostuin fysioterapiasta, minkä jälkeen selvitin ja testasin mahdollisuuksiani kouluttautua alalle. Lopulta opiskelin fysioterapeutiksi ja suureksi helpotuksekseni onnistuin myös työllistymään heti valmistumisen jälkeen.

Kun alanvaihtoa ajattelee kronologisena prosessina ja syy-seuraus-ketjuna, se kuulostaa selkeältä ja helpolta: havaitsin muutostarpeen ja toteutin sen. Aikuiskasvatustieteilijä Mirva Heikkilä on alanvaihtajien ammatillisen identiteetin muutosta koskevassa tutkimuksessaan tunnistanut kolme affektiivista tilaa: irtoaminen, puhdistuminen sekä tulollaan oleminen. Koen käyneeni läpi nuo vaiheet. Jokainen niistä haastoi minua pohtimaan, kuka olen ja missä kulkevat omat rajani, mitä osaan ja mitä oikeastaan tavoittelen. Useimmiten nämä kysymykset nousivat ajatuksiini turhautumista tuottaneiden kokemusten, osaamiseen ja tavoitteisiin liittyvien epävarmuuksien sekä epävarmuuden tuottaman ahdistuksen tunteiden välittäminä.

Prosessiin on sisältynyt omien perusolettamusten, osaamisen, roolien, toimeentulon ja rutiinien kyseenalaistamista sekä uudelleen muotoilua. Matka ei ollut helppo, mutta nyt koen kiitollisuutta itseäni kohtaan ja hymyilen, kun puen ylleni fysioterapeutin työvaatteet.

Ennen alanvaihtoa olin tehnyt tutkijan työtä yliopistolla usean vuoden ajan. Ajatus uramuutoksesta hiipi ajatuksiini hiljalleen. Syitä oli useita: Projektimaailmassa vaikutusmahdollisuudet oman työn jatkuvuuteen tuntuivat heikentyvän vuosi vuodelta. Halusin nähdä enemmän työni käytännön vaikutuksia.
Huomasin, että kehoni kangistui istumatyössä. Sosiaalisena ihmisenä kaipasin tiiviimmin ihmisten pariin.

FYSIOTERAPEUTIN TYÖHÖN TUTUSTUIN erään tutkimusprojektin kenttätyövaiheessa. Myöhemmin olin itsekin fysioterapeutin asiakkaana, ja koin saavani merkittävää apua niskavaivoihini. Kiinnostuin alasta siinä määrin, että aloin opiskella sitä työn ohella avoimessa ammattikorkeakoulussa.

Hiljalleen kiinnostus syveni. Kävin pääsykokeissa ja sain opiskelupaikan fysioterapian englanninkieliseen päiväopetukseen. Olin riemuissani: hieman alle 40-vuotiaana minulle avautui mahdollisuus kouluttautua ammattiin, joka mahdollistaisi sekä uuden uran että jo olemassa olevan osaamisen hyödyntämisen. Aloitin opinnot elokuussa 2015, ja valmistuin fysioterapeutiksi joulukuussa 2018.

Opiskelua vauhdittaakseni anoin hyvitystä muutamasta avoimessa yliopistossa opiskelemistani fysioterapian kurssista. Yllätyksekseni hyvityksen saaminen ei ollutkaan itsestään selvää, vaan yksittäisellä opettajalla oli valta päättää, hyväksytäänkö suoritus vai ei. Koin voimakasta rooliristiriitaa: yhtäältä minulle tarjottiin tiukasti märirteltyä opiskelijan roolia, toisaalta olin omasta oppimisestani vastuussa oleva itsenäinen aikuinen. Minun tuli kärsivällisesti odottaa neuvottelujen tuloksia ja alistua opettajan päätökseen, minkä koin oppimistani hidastavaksi ja häiritseväksi tekijäksi sekä oman osaamiseni osittaiseksi mitätöimiseksi. Neuvotteluprosessit auttoivat minua kuitenkin täsmentämään oman osaamiseni sisältöjä, ja näin myös ammatillinen identiteettini vahvistui.

SIIRTYMINEN AKATEEMISESTA, käsitteellisestä maailmasta kolmiulotteiseen ja fyysiseen fysioterapian maailmaan ei käynyt aivan niin helposti kuin olin ounastellut. Anatomian, ihmisen toimintakyvyn tutkimisen ja mittaamisen sekä liikkumisen ohjaamisen opiskelu edellyttivät koko kapasiteettini hyödyntämistä. 
Opiskelu osoittautui ajoittain kuormittavaksi, sillä ryhmäoppimista painottava opetustyyli jäi omien tavoitteideni osalta joskus vajanaiseksi. Kaipasin usein rauhaa ja tilaa opiskella tavalla, joka on itselleni soveltuvin. Halusin priorisoida asioita, joissa itse koin kehittämistarvetta. Joskus kurssien "käsikirjoitus" saattoi kuitenkin olla niin tarkkarajainen, ettei omalle ajattelulle tai oman tyylin etsimiselle jäänyt tarpeeksi tilaa. Luodakseni aikaa omaehtoiselle opiskelulle ja palautumiselle tehostin opiskelutekniikkaani ja laskin henkilökohtaisia standardejani asioissa, jotka koin jo hallitsevani.

Fysioterapian opiskelussa kehollisuus ja vuorovaikutus korostuvat moninaisin tavoin. Oma ja muiden opiskelijoiden kehot ovat samanaikaisesti oppimisen ja toiminnan kohteina ja välineinä. Oman kehon paljastaminen ja altistaminen muiden katseille, mittaamiselle, testaamiselle ja käsittelylle sekä saman tekeminen toisen ihmisen keholle nostattivat tuntemuksia häpeästä innostukseen. Nyt koen, että tunnen oman kehoni vahvuudet ja heikkoudet hyvin.

Sanallisen ohjaamisen ja kehon liikkeiden ohella fysioterapeutti hyödyntää työssään myös kosketusta ja käsien taitoja. Mielestäni kosketuksen ja kehollisen vuorovaikutuksen oppimista voisi verrata uuden kielen oppimiseen. Omien käsien liike oli alussa kömpelöä, ja toisen ihmisen keho tuntui mykältä käsissäni. Hiljalleen olen alkanut havaitsemaan erilaisia kehollisen vuorovaikutuksen sävyjä ja ymmärtämään sen rikasta kieltä. Tämä on tapahtunut reflektoimalla omaa toimintaani osana vuorovaikutusta sekä tutkimalla ja nimeämällä myös omassa kehossa koettuja tuntemuksia.

TYÖHARJOITTELUT OLIVAT PARASTA oppimisen aikaa. Opiskelun tarkkarajainen käsikirjoitus selkeytti työharjoittelujen tavoitteita ja arviointia sekä edisti oppimisen suunnitelmallista kartuttamista. Toisaalta ne tuottivat joskus keskeytyksiä, etäännyttävää kieltä ja roolien jäykkyyttä työharjoitteluun. Moninaisten arviointien ja vertailujen kohteena oleminen rikasti reflektointikykyä ja täsmensi oman osaamisen ja ammatti-identiteetin osa-alueita. Ajoittain itsensä altistaminen jatkuvalle arvioinnille ja vertailulle tuntui kuitenkin myös turhauttavalta teatterilta.
Kyseenalaistin alanvaihtopäätöstäni erityisesti opintojen loppumetreillä. Ajatuksiin hiipivät epävarmuus työllistymisestä ja tietoisuus siitä, että edessä olisi polku, joka on monelle tuttu uran alkutaipaleelta: lyhyitä sijaisuuksia, epävarmuutta työn jatkuvuudesta, vaihtuvia työyhteisöjä ja aloittaminen työyhteisöhierarkian pohjalta. Lopulta onnistuin saamaan vakituisen työpaikan samalla viikolla kun valmistuin.

Erilaisten luopumisten, epävarmuuden sietämisen ja itsen haastamisen ohella voin nyt todeta, että prosessi antoi uusia sosiaalisia suhteita, uuden ammatin ja työyhteisön sekä seikkailuja erilaisissa työyhteisöissä ja uusilla paikkakunnilla. Ammatillinen identiteettini muotoutuu edelleen, ja etsin tapoja hyödyntää paremmin sosiologian osaamistani fysioterapeutin työssä. Prosessin aikana olen myös saanut kokea, miten toimivia merkitykselliset sosiaaliset suhteeni ovat: olen saanut paljon kannustusta läheisiltäni. Näiden resurssien avulla uskon pitäväni pääni, käteni ja sydämeni synkroniassa ja elinvoimaisina pitkään.

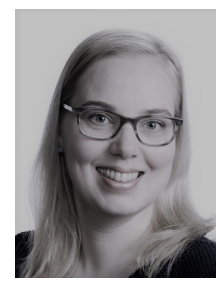

HEIDI KERVINEN

YTM, sosiologi

Bachelor of Health Care, fysioterapeutti 